\title{
Social Economic Development and the Human Resources Management
}

\author{
Prof. Ass. Nada Krypa (Tapija) \\ University "A.Xhuvani”, Elbasan, Economic Faculty
}

\author{
Doi:10.5901/ajis.2017.v6n1p73
}

\section{Abstract}

Bratton \& Gold (2000) stated that socio economic development is playing crucial role in managing human resource progression in developed and developing countries. In the contemporary era developed countries such as USA, UK, Australia and many other European countries are using such progression strategies. National Socio-Economic Development Plan is one of the major strategies that involve welfare of unemployment, poverty, infrastructural development and transportation up gradation. Moreover, socio economic development also includes set up of hospitals and educational institutions (Bambangi, 2007). Such development statistics and process are outlined in various newspapers, magazines and periodical articles. These informative papers help the local human resource management in gaining proper insights on working and economic policies. In the current study importance and relation between socio-economic development and the human resources management will be outlined.

\section{Meaning of Socio-Economic Development}

Mainly socio-economic development can be referred to up gradation of social, political, and technology used in the operational in order to increase welfare of stakeholders. Such policies are helping the countries and firms in developing lifestyles of the stakeholders. They are having the option of educational support, income development, enhancing employee skills and creating more feasible employment. Such development modules are divided into two different segments social and economic (Bristol \& Tisdell, 2010).

Chow (2004) defined Social development as process of leading transformation into the social system and institutions. It is having the objective of improving the capacity of societal members according to the objective of the government or United Nations. Social development implies qualitative change of the peoples in terms of maintaining responsibilities. Currie \& Kerrin (2003) argued that developed countries like USA aims to increase the rate of progressive attitudes and behavior among the peoples in order to increase the proficiency of human capital available in the country. Integrative trainings are provided to the community members for adopting advanced technologies. Social development also includes establishment of various educational and learning systems. However, Gilmore \& Williams (2009) argued that USA and UK faced cross cultural factor, as these countries are having highest foreign immigration. Workplace conflicts are increasing rapidly in the firms which employ people of different backgrounds. Social development policies are aiming to increase collaboration, positive interaction and exchange of beliefs among the employees.

Economic development on the other hand referred to growth of economic prosperity of the country or areas. Residents of the countries like USA, UK, China, India, Australia and many other developed and developing countries are considering economic growth as one of the major responsibility. Financial growth and purchasing power parity are considered as the major indicators of the economic development (Ghorpade, 2004). Countries are using the parameters like the gross domestic product, real national income, and per capita income in order to judge the economic capacity of the peoples. Economic development refers to more in depth boost of country capacity. Such development process is used by the nations in order to improving the economic, political, and social beneficiary of residents and other peoples involved.

Gross Domestic Product (GDP): gross domestic product is the indicators of contrast of the national income generation and production cost within one particular company. Such index is mostly popular indicators of country's economy. GDP is mainly representing the total value of products and services within country borders yearly. Gross domestic income (GDI) is similar to GDP according to their functionality (Hadwen \& Galloway, 2008). 
National Income: it is the overall income generated by residents of any particular company. Income generation covers the labors and capital investments made within the country. Total income includes wages of employees, profits generated by local companies, interests of the debt and investments, rents of the national positions and pension payments. Mainly country's national income is contrasted for one year or six months (Kramar, 2013).

Per Capita Income: in this index calculation entire national income is divided by population of a country. Such statistics will be helping firms and government in terms of the developing pricing strategies and marketing channel as per purchasing capacity. The index outlines individual or per head income generation (McDonnell, 2012).

\section{Human Resource Development}

According to Martin (2009), economic development depicts the income level development of the peoples whereas human resource development outlines development of the skills, knowledge and capability of the peoples. Mainly the strategy covers various employee welfare activities that are adopted by the organizations. Various requirements of the personal lifestyles are required to be maintained in order to motivate and satisfy stakeholders. Mainly HR development strategies are including factors like "economic, social, political, cultural, educational, physical, biological, mental and emotional traits of the peoples related to any organization or country economy" (Kurihara, 2008). Income is a small part of the managing human resources. Individuals are posing diversified needs, which negotiate employee motivation and satisfaction.

"Abraham Maslow's Hierarchy of Needs motivational model" depicted various types of motivational needs of the employees or the individuals (Kramar, 2013). According to Noe (2006), the model employee or human resource development is driven by seven or eight different types of needs recognition or motivational strategies. HR managers are required to maintain all of these factors in order to develop any development strategies. Firstly, individuals are concerned organic and physiological needs it is the most basic requirement. Secondly, development strategies must consider safety or protection needs of the individuals that offer more stability (Pacewicz, 2012).

Apart from the above mentioned needs, socio economic requirements are also need to be maintained in the development strategies. Third part of the model outlines love and belongingness needs of the individuals (Peng \& Li, 2014). Employees will be developed and motivated by increasing the interpersonal relationship, acquaintance, familiarity, fondness and adore among the work groups. Fourth, segment is outlining esteem needs that outlines employees attraction for their organizational positions (Parise, 2007). Moreover, HR managers have to employ cognitive strategies like knowledge and skill development strategies, aesthetic needs like appraisal and motivation, self-actualization needs like potential personal growth and experiences gathering.

However, Qerimi, Hasani \& Rexha (2014) criticized that managements are required to maintain the Human Development Index (HDI) and United Nations Development Program (UNDP). These policies are increasing certain complexity in making smooth transition in employee development and change. Annual Human Development Report policies are used by firms or local authorities. Thus, sustainable development of the human resource is one of the crucial strategies of the management which includes certain sub sections. Social, economic, environmental and individual development is the major sustainable development policies (Bambangi, 2007).

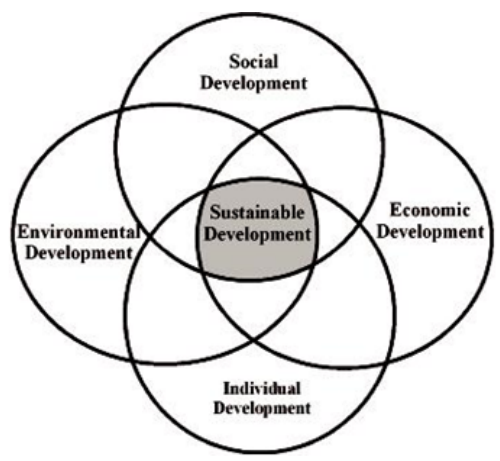

Figure 1: Sustainable development of Human resource

Source: Parise, 2007, p. 361 


\section{Socio-Economic Development and Human Resource Development}

According to Bristol \& Tisdell (2010), socio economic development policies are increasing popularity among the globalised businesses as HR management strategies. Firms are using corporate social responsibilities in order to increase the welfare of human resources. Knowledge development, training, educational system developments are the major part of the CSR. Infrastructural development and technological up gradation are crucial part of the social development (Reinert, 2004). It helps the firms in increasing the productivity and employees engagement. Appraisal, effective compensation, value added provisions, and environmental sustainable strategies are crucial responsibilities of HR managers of the globalised firms like Ford, Microsoft, Nike, Puma, Walmart, Tesco and Adidas (Abdelgalil \& Cohen, 2007).

It has been observed that majority of developed countries like UK and USA based firms are using the "United Nations Development Program (UNDP)" and "Human Development Reports" since the year 1990 (Ti, 2004). In such countries socio economic challenges are incorporated in order to develop human resources. The reports of the above mentioned trials are used by the firms for the future strategic orientation. These policies will be increasing the rate of the affiliation of the firms among the employees or other individual stakeholders (Pacewicz, 2012).

Abdelgalil \& Cohen (2007) stated that human resource management policies of big firms influence socio-economic development of different countries. Earlier it has been observed that economic development strategies did not covered the social wellbeing (McDonnell, 2012). Human resources management strategies are promote growth of employees or stakeholders and economic condition with the help of various factors. International human resource managers are incorporating the political and social instability as per different countries. Henceforth, quality of human capital increases as employees are more satisfied with the help of the CSR or Socio-economic welfare strategies (Noe, 2006). It results high productivity and retention of the loyal employees. According to the globalised business environments productivity is the key of achieving success. Productivity of the employees also depends on the various factors like educational level, management policy and training modules (Pacewicz, 2012).

In addition, Kramar (2013) criticized that the socio economic development also leads to a low wage cost along with higher productivity. This is possible with value added proportions like appraisal and motivation. On the contrary, Gilmore \& Williams (2009) stated that global labor market outlines that in order to make high productivity wages will gradually lift up. Human resource managers are adopting the strategies for increasing on job trainings for the entry level graduates. Such policy helps in increasing the capability of the firms and local labor force. Henceforth, economy of the country will gain a growth and development.

\section{Conclusion}

From the study it has been observed that the socio economic development and human resource management are closely related. CSR and employee engagement are the major socio-economic development strategies of the firms. Mainly HR managers are responsible to increase the motivations and wellbeing of the employees or the stakeholders of the firms. It has been observed that major global firms like Nike, Tesco, ASDA, Walmart, Adidas, Ford and many other are using socio-economic development strategies in order make effective recognition of the employees. These firms are using highly effective reward and motivation strategies in order to increase operational efficiency. Maslow's Hierarchy of needs models are used as the key factors to motivate employees to perform better. Social economic development strategies are one of major aspect of the human resource management. Management need to identify the areas of development and make proper plans to motivate employees that indirectly leads to enhancement of productivity and social responsibility. Socio-economic development strategies that involves creating jobs so that employment level increases along with the personal economic conditions. Henceforth, human resource development will enrich nation GDP level in the developing countries.

\section{References}

Abdelgalil, E. \& Cohen, S. (2007). Economic development and resource degradation: Conflicts and policies. Socio-Economic Planning Sciences, 41(2), 107-129.

Bambangi, S. (2007). Population and socio-economic development in Ghana: Socio-economic development of population management?. Ghana J. Dev. Stud., 4(1), 215-219.

Bratton, J., \& Gold, J. (2000). Human resource management. Mahwah, N.J.: Lawrence Erlbaum.

Bristol, T., \& Tisdell, E. (2010). Leveraging diversity through career development: social and cultural capital among African-American 
managers. International Journal Of Human Resources Development And Management, 10(3), 224.

Chow, I. (2004). Human resource management in China's township and village enterprises: Change and development during the economic reform era. Asia Pacific Journal Of Human Resources, 42(3), 318-335.

Currie, G., \& Kerrin, M. (2003). Human resource management and knowledge management: enhancing knowledge sharing in a pharmaceutical company. The International Journal Of Human Resource Management, 14(6), 1027-1045.

Ghorpade, J. (2004). Management and the human resource function: a model based on social systems theory. International Journal of Human Resources Development And Management, 4(3), 235.

Gilmore, S., \& Williams, S. (2009). Human resource management. Oxford: Oxford University Press.

Hadwen, G., \& Galloway, L. (2008). Continuous professional development via self-directed learning amongst social work professionals. International Journal Of Human Resources Development And Management, 8(4), 346.

Kramar, R. (2013). Beyond strategic human resource management: is sustainable human resource management the next approach? The International Journal Of Human Resource Management, 25(8), 1069-1089.

Kurihara, Y. (2008). Information technology and economic development. Hershey: Information Science Reference.

Martin, J. (2009). Human resource management. Los Angeles: SAGE.

McDonnell, A. (2012). Global Human Resource Management Casebook. The International Journal Of Human Resource Management, 23(7), 155-159.

Noe, R. (2006). Human resource management. Boston, Mass.: McGraw-Hill.

Pacewicz, J. (2012). Tax increment financing, economic development professionals and the financialization of urban politics. SocioEconomic Review, 11(3), 413-440.

Parise, S. (2007). Knowledge Management and Human Resource Development: An Application in Social Network Analysis Methods. Advances In Developing Human Resources, 9(3), 359-383.

Peng, O., \& Li, M. (2014). The Social Management Innovation of Two Dimensional Four Points and The Trinity -Based on the Example of Chongqing Rural Human Resources Development. ASS, 10(18), 117-121.

Qerimi, F., Hasani, V., \& Rexha, D. (2014). The Role of Management in Development of Human Resources in Kosovo. Journal Of Educational And Social Research,10(2), 396-399.

Reinert, E. (2004). Globalization, economic development and inequality. Cheltenham, UK: Edward Elgar.

Ti, L. (2004). Integration to socio-economic development. Pathumthani, Thailand: Asian Disaster Preparedness Center. 